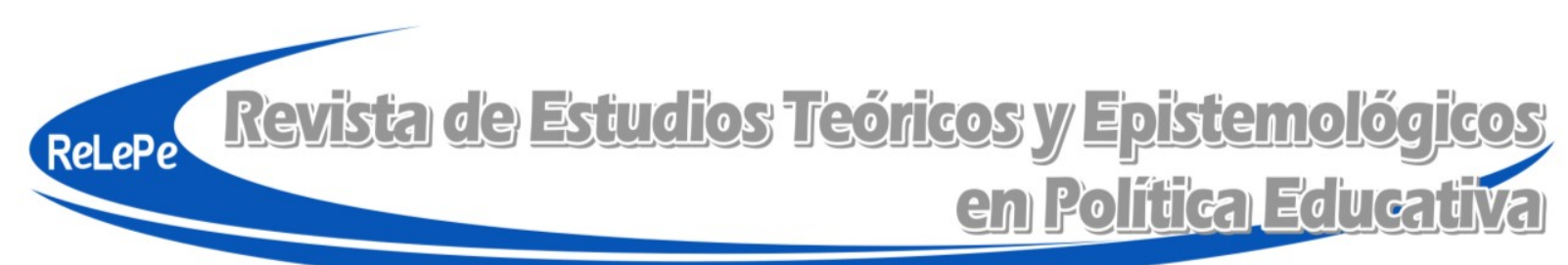

ISSN 2409-3696

DOI: $10.5212 /$ retepe.v.4.005

\title{
Os conceitos de campo e habitus em Pierre Bourdieu e sua (possível) aplicação à Política Educacional
}

\author{
Jorge Nassim Vieira Najjar (UFF) \\ jorgenajjar@gmail.com \\ Marcelo Maia Vinagre Mocarzel (UNILASALLE) \\ marcelomocarzel@gmail.com \\ Pablo Silva Machado Bispo dos Santos (UFF) \\ pablobispo@id.uff.br
}

Resumo: O presente artigo dedica-se a demonstrar a possível aplicabilidade dos conceitos de habitus e campo, cunhados pelo sociólogo Pierre Bourdieu, à pesquisa em educação, em particular, àquela voltada para a política educacional no Brasil. Trata-se de um estudo teórico-epistemológico, que tanto possui características de análise bibliográfica, como também de pesquisa aplicada, na medida em que pretende interagir com as principais correntes de estudos epistemológicos da política pública, em especial, a educacional e com algumas das políticas recentes que se deram em nível nacional. Buscou-se situar o campo da política educacional brasileira a partir de um modelo tridimensional de análise, em que tanto agentes quanto estruturas - e também trajetórias - possam encontrar lugar em uma nova técnica de apreensão dos movimentos do campo educacional. Concluiu-se que a práxis política é entrecortada pelas condições dos agentes e, com isso, a própria compreensão epistemológica da política educacional depende de variáveis muitas vezes intangíveis, na medida em que são condicionadas pelo campo e pelo habitus.

Palavras-chave: Pierre Bourdieu. Pesquisa Educacional. Política Educacional.

\section{Los conceptos de campo y habitus en Pierre Bourdieu y su (posible) aplicación a la Política Educativa}

Resumen: El presente artículo se dedica a demostrar la posible aplicabilidad de los conceptos de habitus y campo, acuñados por el sociólogo Pierre Bourdieu, a la investigación en educación, en particular, a la orientada hacia la política educativa en Brasil. Se trata de un estudio teórico-epistemológico, que posee tanto características de análisis bibliográfico, como también de investigación aplicada, en la medida en que pretende interactuar con las principales corrientes de estudios epistemológicos de la política pública, en especial, la educativa y con algunas de las políticas recientes que se han dado a nivel nacional. Se buscó situar el campo de la política educativa brasileña a partir de un modelo tridimensional de análisis, en que tanto agentes como estructuras -y también trayectorias- puedan encontrar lugar en una nueva técnica de aprehensión de los movimientos del campo educativo. Se concluyó que la praxis política está entrecortada por las condiciones de los agentes y, con ello, la propia comprensión epistemológica de la política educativa depende de variables a menudo intangibles, en la medida en que están condicionadas por el campo y el habitus.

Palabras clave: Pierre Bourdieu. Investigación Educativa. Política Educativa. 


\title{
The Pierre Bourdieu's concepts of field and habitus and their (possible) application to Education Policy
}

\begin{abstract}
This article aims to demonstrate the possible applicability of the concepts of habitus and field, coined by sociologist Pierre Bourdieu, to research in education, in particular, that focused on educational policy in Brazil. It is a theoretical-epistemological study, which has both characteristics of bibliographical analysis and applied research, insofar as it intends to interact with the main currents of epistemological studies of public policy, especially, educational and with some of the policies that have taken place at the national level. We sought to situate the field of Brazilian educational policy from a three-dimensional model of analysis, in which both agents and structures - and also trajectories - can find place in a new technique of apprehension of the movements of the educational field. It was concluded that political praxis is broken by the conditions of the agents and, with this, the epistemological understanding of educational policy itself depends on variables that are often intangible, inasmuch as they are conditioned by the field and the habitus.
\end{abstract}

Keywords: Pierre Bourdieu. Educational Research. Educational politics.

\section{Introdução}

A educação é, antes de tudo, um campo multidisciplinar e internacional. Melhor ainda, a educação é um campo transdisciplinar e multidimensional, no que se refere aos aportes teóricos utilizados, tanto como ciências fonte - para usar a expressão célebre de Anísio Teixeira - como ciências objeto. A esse respeito ele mesmo assinala:

A educação pode, com alguns raros expoentes, atingir o nível das belas-artes, mas, em sua generalidade, quase sempre, não chega a essa perfeição, conservando-se no nível das artes mecânicas ou práticas, entendidos os termos no sentido humano e não no sentido de maquinal, restritivo apenas quanto a belo e estético. O progresso nas artes - sejam belas ou mecânicas - se fará um progresso científico, na medida em que os métodos de estudo e investigação para este progresso se inspirem naquelas mesmas regras que fizeram e hão de manter o progresso no campo das ciências, ou sejam as regras, para usar expressão que não mais se precisa definir, do "método científico". A passagem, no campo dos conhecimentos humanos, do empirismo para a ciência foi e é uma mudança de métodos de estudo, graças à qual passamos a observar e descobrir de modo que outros possam repetir o que observarmos e descobrirmos e, assim, confirmar os nossos achados, que se irão, de tal maneira, acumulando e levando a novas buscas e novas descobertas. Se esta foi a mudança que originou os corpos sistematizados de conhecimentos a que chamamos de ciências, um outro movimento, paralelo ao das ciências e dele consequente, mas, de certo modo autônomo, foi o da mudança das "práticas" humanas pela aplicação do conhecimento científico (TEIXEIRA, 1957, p. 7-8).

Dessa forma, continua Teixeira, no tocante à especificidade da educação, há uma visão da mesma como ciência aplicada e ao mesmo tempo como campo interdisciplinar, de forma que, para que tenha as características do progresso científico, sejam observadas "condições de desenvolvimento inteligente, controlado, contínuo e sistemático" (TEIXEIRA, 1957, p. 8). Mas, não se trataria de criar uma pretensa ciência da educação que, segundo ele, não existe e nem poderia existir, 
[...] mas de dar condições científicas à atividade educacional, nos seus três aspectos fundamentais - de seleção de material para o currículo, de métodos de ensino e disciplina, e de organização e administração das escolas. Por outras palavras: trata-se de levar a educação para o campo das grandes artes já científicas - como a engenharia e a medicina - e de dar aos seus métodos, processos e materiais a segurança inteligente, a eficácia controlada e a capacidade de progresso já asseguradas às suas predecessoras relativamente menos complexas. Está claro que essa inteligência da arte de educar a afasta radicalmente das artes predominantemente formais, como a do direito, por exemplo, à qual, me parece, temos, como país, uma irresistível inclinação a identificar a educação (TEIXEIRA, 1957, p. 8-9).

Nesse sentido, a partir dessas "pistas", igualmente se deve ter em conta que as múltiplas interfaces entre a educação e outras ciências encontram na política educacional um lócus privilegiado de pesquisa, e, de certo modo, de luta política. Assim sendo, tanto a interface jurídico-política da educação quanto outras interfaces, a saber, avaliação, currículo, didática, psicologia, história e sociologia etc. são fundamentos da educação (ou ciências fontes). Entendemos que estas são passíveis de análises, desde que não tenham uma linearidade causal, tampouco um reducionismo que procure imputar a fatores únicos e unívocos os fenômenos observados na pesquisa, quando aplicada à concretude da prática, seja esta a prática escolar, seja esta a prática da análise dos planos, ações, programas e desdobramentos das políticas públicas.

No que concerne especialmente ao campo da política educacional, devemos ter em conta que as análises que são empreendidas no Brasil devem muito aos campos de estudo vinculados à área de conhecimento das políticas públicas, em sentido lato. Assim sendo, torna-se necessário não somente um conhecimento mais aprofundado acerca deste campo, advindo da ciência política, quanto também se torna primordial procurar novas metodologias de investigação que possam produzir instrumentos de pesquisa aplicados à área de conhecimento.

O objetivo deste artigo é apresentar a contribuição dos conceitos de habitus e campo, da teoria de Pierre Bourdieu à pesquisa em política educacional. Nesse sentido, cabe indicar que não nos deteremos somente na associação direta desses conceitos ao já mencionado campo teórico; procuraremos, antes disso, realizar uma breve explanação acerca da teoria bourdieusiana de campo e seus conceitos associados, de modo a situar o leitor no âmbito teórico do que pretendemos tratar. Em seguida, trazemos uma aplicação desses conceitos teóricos ao campo da política educacional, de modo a desenvolver um modelo analítico derivado da junção entre as características do campo da política educacional, em especial da política educacional brasileira, à teoria bourdieusiana. Ao final deste estudo, procuramos contribuir para a construção de uma metodologia de análise de políticas públicas educacionais que possa superar tanto o monismo metodológico quanto o ecletismo incongruente ${ }^{1}$.

O que seria, então, uma metodologia? A grosso modo, nada mais é do que uma articulação entre as ferramentas teóricas, os resultados da aplicação dessas ferramentas ao campo empírico e uma descrição dos passos que se adota (ou que se pretende adotar) ao longo da

\footnotetext{
${ }^{1}$ Estas são perspectivas teórico-metodológicas que frequentemente conduzem a equívocos os mais diversos, tais como: a) a utilização monolítica de técnicas de pesquisa; b) a consideração monocausal de fenômenos sociais complexos; c) a construção de modelos teórico metodológicos "híbridos" a partir de autores e pontos de vista que muitas vezes são dissonantes ou mesmo antagônicos. Na área de educação isto às vezes se verifica, e, devido justamente a estas duas tendências procuramos um viés teórico que não incorresse nestes dois entraves à compreensão advindos de noções teórico-epistemológicas que produzem numerosos equívocos em termos de análise, como, por exemplo: considerar somente fatores econômicos ao analisar realidades complexas como a aprendizagem escolar em uma rede de ensino, ou, procurar a partir de explicações "híbridas" explicar resultados de pesquisa sobre evasão escolar a partir de autores antagônicos do ponto de vista teórico.
} 
pesquisa. Isso precisa ser feito de forma clara, explicitando quais autores dão base para as técnicas, quais autores dão base para a demonstração, da maneira mais inequívoca possível, bem como devem ser identificados quais são e como são as suas fontes, quais são e como são as suas técnicas, quais são e como são os resultados esperados.

Após esse processo de objetivação, eis a parte interpretativa da metodologia, em que todos os instrumentos passam a fazer sentido (ou deveriam passar a fazer), devido ao fato de terem sido organizados de modo a gerar uma elocução discursiva coerente com a empiria delimitada e com as matrizes teóricas delimitadas. Após esta tarefa, eis a objetivação da objetivação, ou seja, a verificação da aplicabilidade e veracidade concernente à teoria, à empiria e às técnicas de estudo / pesquisa. Esta nada mais é do que a validação dos dados. Em se tratando de pesquisa quantitativa, o critério de validação se refere à representatividade da amostra ${ }^{2}$, enquanto que em matéria de pesquisa qualitativa, normalmente este se refere à triangulação ${ }^{3}$ (TRIVIÑOS, 1987). Apesar destes não serem os únicos critérios de validação possíveis, os mesmos foram elencados devido ao caráter modelar e, de certo modo, exemplar, no que tange às pesquisas científicas nas ciências humanas e sociais.

\section{Sociedade e mundo social: preliminares epistemológicas a uma análise reflexiva}

A noção de sociedade presente na obra de Pierre Bourdieu é diferente da que muitos sociólogos utilizam e utilizaram ao longo do tempo. Contraposta a visões lineares, como a da sociologia marxista, a noção de sociedade em Pierre Bourdieu é substituída pela noção de mundo social, e a noção de estrutura social é substituída pela noção de campo, que passa a ser a unidade explicativa de grande escala utilizada pelo pensador.

Para compreender o que Bourdieu chama de mundo social (e que conjuga estruturas, indivíduos, grupos, habitus e diversas modalidades de capital), devemos entender que para este autor o espaço social é composto por campos, os quais se compõem de diversas forças sociais atuantes, forças estas encarnadas nas estruturas e nos agentes.

A posição dos elementos do campo, ao contrário das teorias que pressupõem uma linearidade estrutural (como postulado por certas apropriações simplistas da teoria marxista, que apresentam como se fora uma petitio principii a existência de classes sociais), é definida pelo modo como tais elementos se relacionam entre si, e suas variações em função do volume global e da estrutura dos diversos tipos de capital (como capital cultural, econômico, simbólico e informacional) de acordo com a natureza do campo em que tais relações se desenvolvem.

A Título de ilustração, tomemos como exemplo, em um campo que se pode chamar acadêmico, as regras de valorização dos indivíduos e estruturas se dá a partir da posse de capital cultural dos mesmos, em detrimento da posse de outro tipo específico de capital (como o capital econômico). Deste modo, o conceito de classes sociais acaba sendo substituído por recursos de poder explicativos muito diversos (em nível epistemológico), como por exemplo: a perspectiva que relaciona indivíduos, estruturas, habitus e tipos de capital com regras pertinentes a cada campo do mundo social e que Bourdieu sintetizará em sua magistral assertiva: "O real é relacional" (BOURDIEU; CHAMBOREDON; PASSERON, 2004, p. 109).

\footnotetext{
2 Tal critério por sua vez tem a ver com a possibilidade de inferir dados relativos ao universo da pesquisa a partir da amostra delimitada como campo empírico e objetivada na pesquisa em questão.

3 A triangulação diz respeito ao critério a partir do qual o mesmo objeto é submetido a diferentes técnicas de pesquisa, e, se possível, a diferentes vertentes teóricas, de modo a que após tal subsunção o pesquisador possa avaliar a coerência intrínseca e extrínseca dos resultados, testados mediante tal procedimento.
} 
O mundo social é então a alternativa teórica oferecida por Bourdieu à noção vaga, imprecisa e polissêmica de "sociedade". A referida alternativa, por sua vez, possui uma abrangência que permite a realização de aproximações analógicas com o mundo físico, no sentido de que o mesmo também possui diversas camadas, coordenadas geográficas, diferenças meteorológicas e outras. Por definição, o mundo social possui uma natureza que exige o desenvolvimento de uma epistemologia própria, a qual não pode ser monocausal ou linear, mas sim complexa e reflexiva, tanto no tocante à teoria e à metodologia quanto ao escopo dos objetos que são tomados como elementos de análise, a qual deve seguir o imperativo da vigilância epistemológica, ou seja, o controle sistemático dos métodos, técnicas e vieses teóricos, bem como sobre a dimensão subjetiva do pesquisador em interação com o objeto de análise.

\section{Sobre habitus e campo: sua aplicabilidade e pertinência teórica discutidas}

Habitus e campo guardam uma relação indissociável, são dois conceitos com geometria variável, relativos e ao mesmo tempo presentes no que tange a certas invariantes simbólicas, para utilizar a expressão cunhada pelo pensador Ernst Cassirer (2001). Seguindo esta linha de raciocínio, habitus e campo dentro, da perspectiva bourdieusiana, são nada mais nada menos do que estruturas simbólicas estruturadas e estruturantes ${ }^{5}$.

A noção de mundo social, trazida por Pierre Bourdieu, possui, em termos teóricos, a necessidade de uma teoria, de uma epistemologia e de uma(s) metodologia(s) própria(s), tal como ocorre com os fenômenos físicos da "realidade tridimensional" (SANTOS, 2013). Ainda que não se chegue a este nível de detalhamento/aprofundamento, a utilização de conceitos bourdieusianos como habitus, campo e mundo social trazem algumas necessidades teóricoempíricas. A primeira é a de que tanto o habitus como o campo possuem sempre alcance relativo à realidade em que se busca utilizar.

Decorrente desta primeira necessidade, temos o (obrigatório) reconhecimento de que estes são conceitos que ensejam uma dupla reflexibilidade: a) são reflexivos, no sentido em que a sua relação de proximidade guarda influências mútuas, seja no nível subjetivo, seja no nível coletivo ou social. Se assim preferirmos, o princípio da reflexividade dos conceitos se mantém na medida em que determinado campo irá influenciar processos de geração do habitus, ao mesmo tempo em que o habitus dos agentes trazido por intermédio das estruturas sociais presentes no campo (instituições, modus operandi em nível moral, ético e comportamental, bem como em termos concretos, as próprias agremiações ou associações coletivas que engendram corpus de práticas, pensamentos coletivos (ideias-força) e formas de dividir o mundo a partir de esquemas hierárquicos de classificação simbólica) influem na constituição do campo. Tal interação irá modificar a estrutura e formação simbólica e, por vezes, material do campo a que estamos nos referindo. Assim sendo, o caráter dinâmico do campo torna-se passível de uma analogia com a metáfora física de um campo de forças e cargas eletromagneticamente orientadas, tal como

\footnotetext{
${ }^{4}$ Neste sentido, cabe ressaltar a pertinência desta noção enquanto metáfora da totalidade aplicada às interações humanas inter e intra subjetivas.

${ }^{5} \mathrm{O}$ habitus vem a ser estrutura estruturante, devido ao fato de ser por excelência o mecanismo que engendra no indivíduo esquemas práticos (não racionais) ligados a princípios de visão e divisão do mundo, coordenação dos múltiplos hábitos e condicionante da hexis corporal dos mesmos (SANTOS, 2007). Apesar disso, o babitus não é inato, mas sim a resultante do trabalho lento e progressivo de inculcação no indivíduo dos esquemas assimilados mediante o convívio em sociedade, indo da dimensão simbólica da cultura até a dimensão prática da ação social. $\mathrm{O}$ campo, por sua vez, sendo estrutura estruturante das coletividades é composto por conjuntos de elementos que se comportam como forças em disputa, ou, luta concorrencial. Tais elementos por sua vez são estruturas e agentes em constante interação, o que significa que o estado de um campo vem a ser resultante (dinâmica) do momentum de correlação entre tais forças (BOURDIEU, 2001b).
} 
poderemos ver no trabalho elaborado por Jeremy Lane no que tange à aplicação política dos conceitos de habitus e campo de Pierre Bourdieu'; b) a reflexividade dos conceitos de habitus e campo por sua vez, tal como disse Pierre Bourdieu no seu texto "Por uma sociologia reflexiva", que aborda justamente a capacidade de refletir e compreender e que, no caminho entre o empírico e o teórico, existe uma instância que deve ser delimitada justamente pelas condições em que o campo se situa, pois trata-se de estrutura ao mesmo tempo material, simbólica e social, cujas interações são sempre determinadas (ou pelo menos condicionadas) por regras que são inerentes a cada campo, as quais, por sua vez, movem os agentes em direção ao que Bourdieu denomina illusio, que nada mais é do que um conhecimento prático das regras do jogo de determinado campo (e que se incorpora aos agentes por meio do babitus).

Assim sendo, determinados agentes conseguem circular entre os campos da sociedade e assimilar esquemas mentais, comportamentais e simbólicos com mais facilidade que outros devido à sua estrutura e volume de capital, passível de conversão de um campo ao outro por um efeito de analogia estrutural.

Com o fito de esclarecer o que fora exposto, tomemos o caso de alguém que nunca teve contato com o campo acadêmico de uma universidade mas que fez algum tempo de carreira militar, chegando a se tornar oficial. A sua disciplina de estudo e de lidar com o tempo, oriundas do subcampo educacional militar, em suas diferentes divisões e também em suas diferentes necessidades de ação, fazem com que este habitus ativo (de prontidão) tenda a levar o indivíduo muitas vezes a transpor esta disciplina de cumprimento de tarefas incorporada ao seu babitus para o ambiente de estudo acadêmico fazendo com que tal indivíduo possa vir até mesmo a atingir altas posições naquilo que chamaremos de campo do poder ${ }^{7}$.

Nesse sentido, tomando como base o referido exemplo há que se considerar que em ambientes como escolas e universidades, indivíduos cuja vivência cultural e social prévia (ou concomitante) à escolarização formal possuem elementos de ação prática que os levam a ter desempenhos diferenciados ao desempenhar tarefas escolares por meio da "ativação" do seu babitus por um efeito de analogia.

\section{Habitus, campo e política educacional: esboço de um modelo analítico multidimensional}

Será apresentado a seguir um esboço de modelo analítico multidimensional de políticas públicas, o qual precede a subsequente estruturação do exame do campo das políticas públicas educacionais no Brasil, possuidor de um arcabouço teórico-metodológico que mescla análise histórica a análise político-social. Vamos então ao modelo.

Este mecanismo analítico se comporia de alguns passos indicados na sequência a seguir. Tal sequência é identificada por Lane (2006) em sua obra "Bourdieu politics". Em relação ao primeiro dos passos indica que:

\footnotetext{
${ }^{6}$ No livro "Bourdieu: politic problems" (2006), o autor norte-americano Jeremy Lane realiza um ensaio sobre a aplicação em nível estrutural dos conceitos de campo, habitus e mundo social ao estudo da ciência política.

${ }^{7} \mathrm{O}$ campo do poder, para Pierre Bourdieu, consiste na fração do campo a partir do qual a influência chega até a deformar o Campo devido à concentração de capitais dos agentes detentores dos mesmos. Há que considerar o Campo do Poder como o local em que se situam as estruturas e agentes que atendem plenamente à definição magistral do sociólogo francês quando refere-se a estes como os dominantes entre os dominantes (BOURDIEU, 2001).
} 
Tendo identificado os agentes qualificados como "agentes eficientes" nesse contexto, Bourdieu coletou uma massa de dados biográficos sobre cada um deles, incluindo origem social, educação, carreira e trajetória, antes de traçar esses dados por meio da análise de correspondência [Tradução nossa] (LANE, 2006, p. 78$)^{8}$.

Com base nesta citação há que se considerar (conforme veremos a seguir) a possibilidade de agregar à análise elementos contextuais passíveis de extração mediante o emprego de técnicas de análise documental, bem como, de análise de discurso. Porém este seria um primeiro passo, prévio à investigação de maior profundidade. Por outro lado, um intróito em matéria de esquematização analítica pode ser visto no esboço de gráfico que trazemos a seguir:

Diagrama 1 - Espaço Social e Simbólico do Campo delimitado

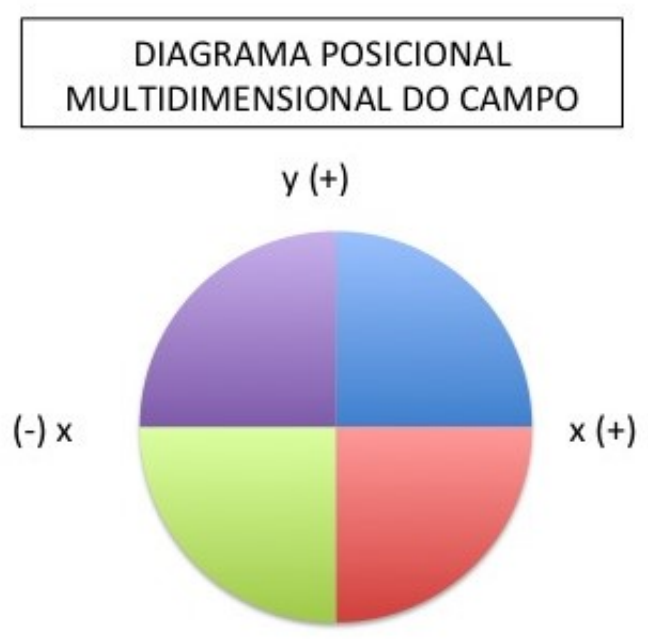

$(-) y$

Fonte: Elaborado pelos autores.

A partir deste esboço serão atribuídas aos eixos $\mathrm{X}$ e $\mathrm{Y}$ do gráfico, propriedades que correspondem às características (neste caso específico: Volume de Capital e Estrutura de Captal) dos agentes e estruturas que pretendemos não somente analisar, mas também tornar "concretas" as suas posições no que se refere a relações de poder. Nesse sentido, cabe ainda ressaltar que a geratriz bidimensional correspondente ao "ponto zero" de tais eixos é ainda atravessada por vetores tangenciais correspondente a outros Campos quando é realizada uma análise de conjuntura utilizando espectro mais amplo de abrangência temática (ex: Campo Educacional do Brasil x Campo Econômico da América Latina), porém não nos deteremos na análise destes casos possíveis mas não ligados ao objeto do presente trabalho.

No tocante ao segundo dos passos da construção do instrumento analítico, seguindo o raciocínio do autor temos, após a identificação dos "agentes eficientes" (os agentes que agem de modo diferenciado e dominante em relação ao campo), e do conhecimento a respeito de sua trajetória social, por meio da aplicação de um tipo de análise multivariada destas posições temos as seguintes descrições:

\footnotetext{
${ }^{8}$ No texto original temos: "Having identified those agents who qualified as 'efficient agents' in this context, Bourdieu collected a mass of biographical data about each of them, including social origin, education, career and social trajectory, before plotting that data by means of correspondence analysis" (LANE, 2006, p. 78).
} 
Os conceitos de campo e habitus em Pierre Bourdieu e sua (possível) aplicação à Política Educacional

A análise de correspondência é uma forma de análise multivariada que, dada uma amostra de, neste caso, indivíduos, definidos por um número de variáveis diferentes, primeiro identifica quais dessas variáveis são as mais distintivas. As duas variáveis mais distintas geralmente servem como eixos horizontal e vertical de um gráfico que procura traçar, espacialmente, as coordenadas do "campo" em questão [Tradução nossa] (LANE, 2006, p. 78)99.

Utilizando as técnicas inspiradas no que apresenta o autor da citação é possível (e desejável, diríamos) a construção de um gráfico vetorial bidimensional tal como o apresentado a seguir:

Diagrama 2 - Sistema de coordenadas de Volume e Estrutura de Capital do Campo

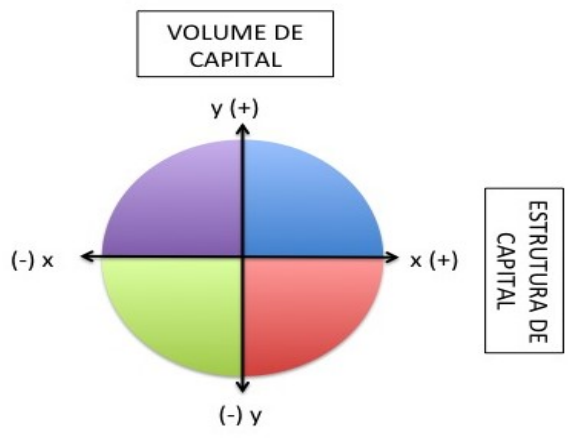

Fonte: Elaborado pelos autores.

Após a definição das variáveis influenciadoras do campo (neste caso: Volume e Estrutura de Capital) e a construção dos dois eixos estruturais (e estruturantes) da análise, eixos estes correspondentes às duas variáveis com maior força de condicionamento do referido Campo (e devidamente convertidos em abscissas e ordenadas), há um terceiro passo apresentado pelo autor:

Esses dois eixos se dividem em seus pontos médios, originando um gráfico composto de quatro quadrantes opostos, dentro do qual as posições relativas de cada indivíduo são plotadas. Características secundárias, menos variáveis distintivas, também influenciam a posição de cada indivíduo, já que a análise funciona gerando um "cluster" de atributos aos indivíduos, "agrupando-os". Os indivíduos com perfis semelhantes se posicionam próximos uns dos outros, enquanto aqueles com perfis muito diferentes estão situados a alguma distância, agrupados em um quadrante diferente do gráfico [Tradução nossa] (LANE, 2006, p. 79) ${ }^{10}$.

\footnotetext{
9 A versão base desta citação corresponde a: "Correspondence analysis is a form of multivariate analysis which, given a sample of, in this case, individuals, defined by a number of different variables, first identifies which of those variables are the most distinctive. The two most distinctive variables typically serve as the horizontal and vertical axes of a graph which seeks to plot, spatially, the coordinates of the 'field' in question" (LANE, 2006, p. 78).

${ }^{10}$ No original da citação veremos o seguinte texto: "These two axes bisect one another at their mid-points, giving a graph composed of four opposing quadrants, within which the relative positions of each individual are then plotted. Secondary characteristics, less distinctive variables, also influence the position of each individual since the analysis works by giving a 'profile' of attributes to individuals and 'clustering' those individuals with similar such profiles close to one another, while those with very different profiles are situated at some distance, clustered in a different quadrant of the graph" (LANE, 2006, p. 79).
} 
Ao fazer um exercício de esquematização gráfica sequencial e correspondente ao que já fora iniciado, temos neste passo um diagrama tal como o que apresentamos a seguir:

Diagrama 3 - Exemplo de distribuição dos elementos no campo

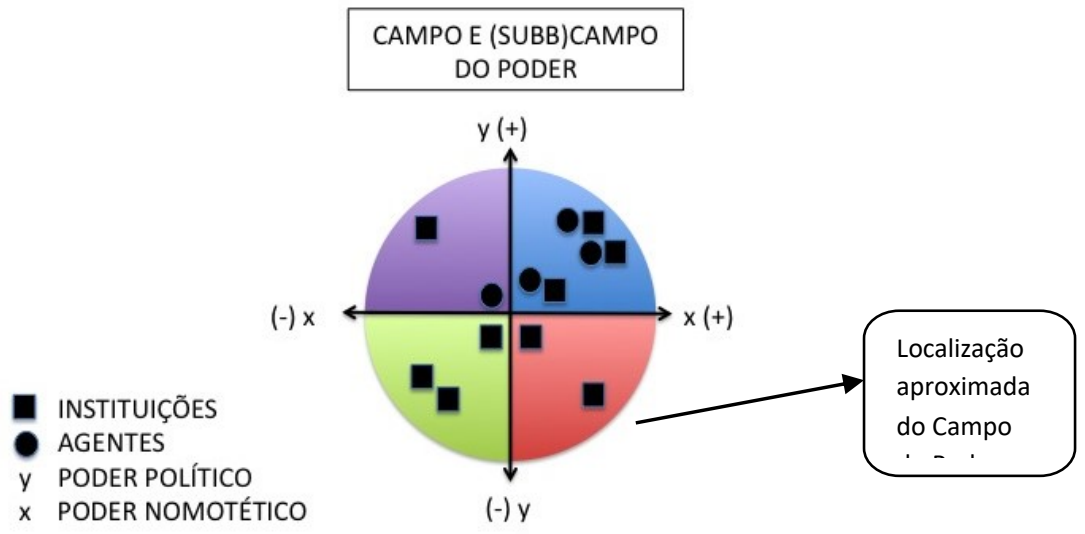

Fonte: Elaborado pelos autores.

Os quadrantes de análise, definidos a partir de posições negativas e positivas de acordo com suas propriedades e de acordo com as matrizes delineadas pelas variáveis mais fortes do Campo auxiliam no mapeamento dos mesmos. O trabalho de Lane (2006) representa assim um avanço importante na questão do entendimento da práxis política, em especial no que se refere à apreensão da materialidade dos agentes e dos grupos envolvidos nas disputas pelo poder em cada um destes campos.

No gráfico apresentado, é possível perceber que a "zona" do Campo denominada (sub)Campo do Poder é representada no gráfico como um ponto que combina a intercessão das abcissas e ordenadas com a região mais exterior do Campo. Isto é feito com o intuito de demonstrar que não somente os assim chamados "dominantes" detém maior estrutura e volume de capital no Campo considerado como também estão mais próximos de outros Campos (caso sejam considerados na análise) de onde podem realizar diversas trocas e combinações entre seus capitais.

Deve ser acrescentado ainda, que a combinação entre diversas técnicas de pesquisa (tais como: análise documental, análise de impacto e análise de discurso entre outras) para a captação das relações de poder e seu conseqüente posicionamento em um esquema de análise gráfica, temos em nível concreto, ao utilizarmos este sistema gráfico, mais uma estrutura modelar para o exame das políticas públicas e seus desdobramentos.

De maneira a aplicar este raciocínio e desdobrar o mesmo ao status quo do Campo da Política Educacional no Brasil, complexificamos o sistema gráfico, o qual apresentamos a seguir: 
Os conceitos de campo e habitus em Pierre Bourdieu e sua (possível) aplicação à Política Educacional

Diagrama 4 - Aplicação da metodologia gráfica descritiva ao Campo da política Educacional no Brasil

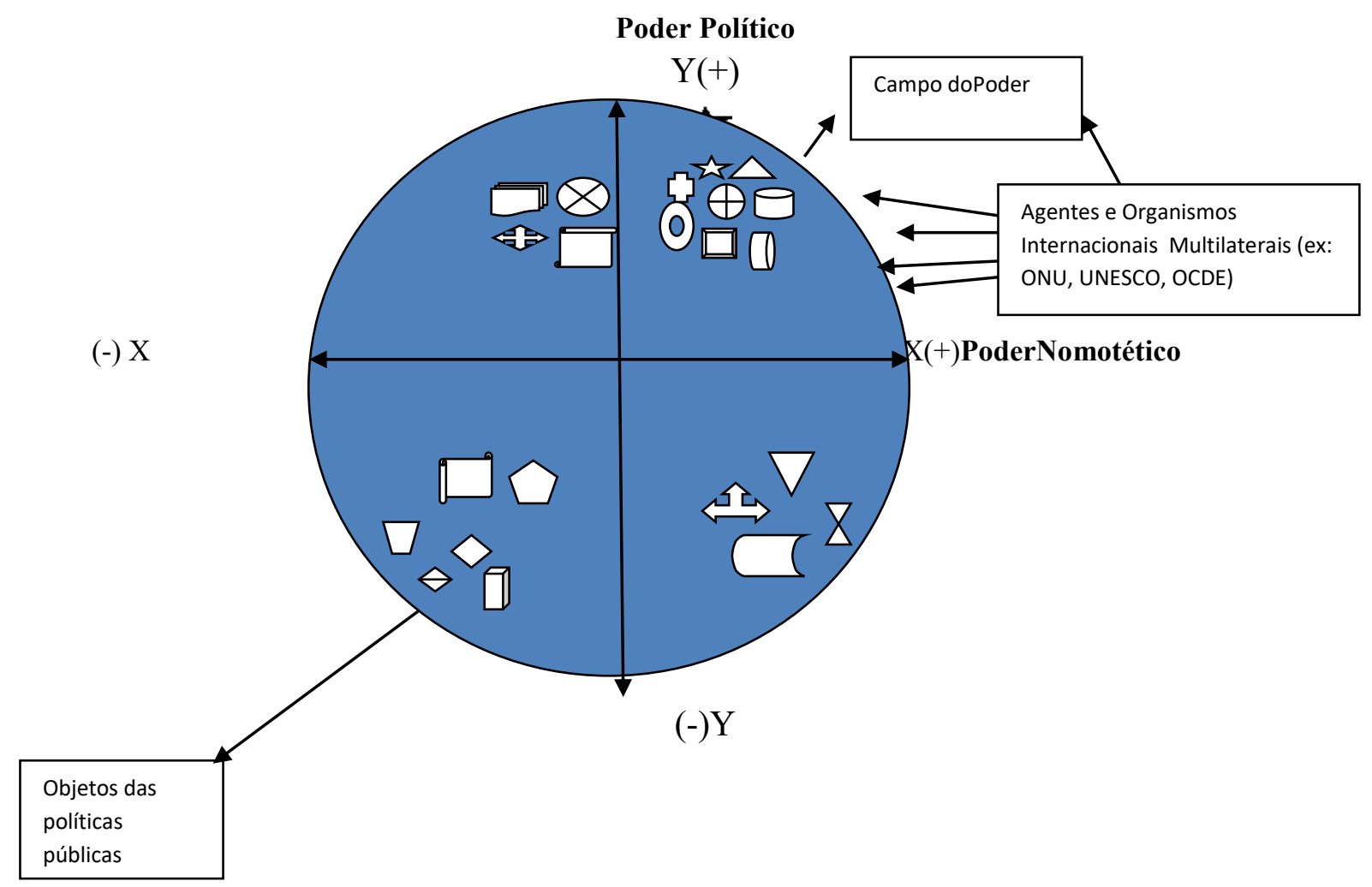

\section{Legendas}

\begin{tabular}{|c|c|}
\hline Estruturas/Instituições & Agentes \\
\hline$\hat{z}=$ Congresso Nacional & $\begin{array}{l}\bigoplus_{\text {Deputados. }}=\text { Presidente do Senado e Câmara dos } \\
\text { Dato }\end{array}$ \\
\hline$\triangle=$ Ministério da Educação - MEC & $(0)$ Ministros do STF e STJ. \\
\hline \=Ministério do Planejamento & $\square$ = Ministros de Estado (MEC incluído). \\
\hline$\bigoplus$ Conselho Nacional de Educação - CNE & (O) = Conselheiros integrantes do CNE \\
\hline $\begin{array}{l}\square \text { = Secretarias de Educação (Municípios e } \\
\text { Estados) }\end{array}$ & $\diamond=$ Professores / gestores da Educação Básica \\
\hline$\nabla=$ Sindicatos de Profissionais da Educação & $\begin{array}{l}\emptyset_{\text {Superior. }}=\text { Professores / Gestores da Educação } \\
\end{array}$ \\
\hline $\begin{array}{l}\varrho_{\text {Científicas. }} \text { Associaços Educacionais, Técnicas e } \\
\end{array}$ & $\begin{array}{l}\square=\text { Dirigentes de Associações Educacionais e } \\
\text { Técnico /Científicas }\end{array}$ \\
\hline$\bigotimes=$ Movimentos Sociais & $\begin{array}{l}\text { = Líderes de Movimentos sociais ligados a } \\
\text { Educação. }\end{array}$ \\
\hline $\begin{array}{l}\nabla=\text { Ministério Público - MP (MPU, MPF, e MP } \\
\text { Estadual). }\end{array}$ & $\underset{\text { Estadual). }}{\stackrel{\text { D }}{\longrightarrow}=\text { Agentes do MP (MPU, MPF, e MP }}$ \\
\hline $\begin{array}{l}Z=\text { Tribunais de Contas e Controladoria Geral da } \\
\text { União - CGU. }\end{array}$ & $C=$ Agentes dos Tribunais de contas e CGU. \\
\hline $\begin{array}{l}\square=\text { Conselhos da Sociedade Civil } \\
\text { (EX: CNE, C,E.C, Conselho do FUNDEB) }\end{array}$ & $\begin{array}{l}\text { C, Conselheiros da Sociedade Civil (EX: CNE, } \\
\text { C,E.C, Conselho do FUNDEB) }\end{array}$ \\
\hline
\end{tabular}

Fonte: Elaborado pelos autores. 
Conforme se pode perceber, este é um sistema gráfico de grande complexidade e que aplica a metodologia de descrição gráfica do Campo trazida por Lane (2006) e esboçada em termos genéricos anteriormente. O referido gráfico, além de buscar captar o momento do Campo, procura também identificar quais são os agentes mais proeminentes e como sua ação se expressa, representando isto não somente a partir da sua distribuição pelos quadrantes (o eixo Y representa o Volume de Capital, que denominamos Poder Político, e, o eixo X denomina a estrutura de capital, a qual atribuímos a nomenclatura de Poder Nomotético), mas também pelo modo como tais agentes distam ou se aproximam entre si. É justamente devido a este nível de construção analítica minuciosa que tal diagrama possui um número tão grande de legendas e formas.

Por último, mas nem por isso menos importante, cabe destacar que a representação gráfica ora apresentada corresponde ao período referente ao ano de 2018. Vamos então à análise destes elementos.

\section{O “Campo do Poder" na Política Educacional atual: seus agentes e estruturas}

A região mais próxima do "Campo do Poder" (quadrante das coordenadas $\mathrm{X}+$ e $\mathrm{Y}+$ ) apresenta oito elementos: a) quanto às estruturas temos: Congresso Nacional, Ministério da Educação, Ministério do Planejamento e Conselho Nacional de Educação; b) no tocante aos agentes há a distribuição do(s) Presidente(s) da Câmara dos Deputados e do Senado Federal, Ministros de Estado, Ministros do Superior Tribunal Federal e Superior Tribunal de Justiça e Conselheiros integrantes do Conselho Nacional de Educação.

Em relação às instituições/estruturas atuantes na Política Educacional Brasileira em nível Macro, há que ser salientado que as mesmas se distribuem no quadrante a partir do seguinte posicionamento:

1) MEC e o Congresso Nacional possuem a posição mais elevada no "Eixo X", além de encontrarem bastante avançados no "Eixo Y", isto significa que estes entes institucionais são os que concentram maior volume (poder político) e "melhor" estrutura de Capital no Campo considerado. Isto os torna inclusive mais próximos dos elementos internacionais condicionantes da Legislação e da Política Educacional vigente, detendo parte de seu poder nomotético e Político da influência desta posição de poder próxima à "fronteira do Campo"11.

2) Em posição próxima nos eixos $\mathrm{X}$ e $\mathrm{Y}$, porém pouco menos próxima ao Campo do Poder se situam o Ministério do Planejamento e o Conselho Nacional de Educação. Ambos possuem menos poder político e nomotético (representados nos Eixos X e Y), porém ainda assim estão próximos do Campo do Poder pois cabe ao Ministério do Planejamento o repasse de recursos financeiros para a Educação enquanto que cabe ao Conselho Nacional de Educação a normatização e deliberação acerca dos atos administrativos (e políticos) do MEC.

No que diz respeito aos agentes representados no diagrama e que ilustram o "Campo do Poder” da Política Educacional Brasileira, temos por analogia a seguinte distribuição:

1) Presidentes da Câmara e do Senado ocupam a posição que concentra maior poder nomotético e volume de capital (poder político) em quantidade que lhes permite maior proximidade com o Campo do Poder, é destes agentes que emana a decisão maior sobre normas

\footnotetext{
${ }^{11}$ É assaz relevante recordar que no Brasil, acordos e tratados internacionais possuem estatuto equivalente ao de Legislação Infraconstitucional Federal.
} 
e regras referentes à Política Educacional Brasileira, o que se dá devido a suas funções na hierarquia administrativa do Estado Brasileiro enquanto grandes mandatários do Poder Legislativo, estando no ápice do poder político e Possuindo igualmente poder normativo (nomotético).

2) Ministros do STJ e STF e Ministros de Estado, possuem uma equivalência no que diz respeito ao poder nomotético (lembrando que os Ministros de Estado enquanto agentes são executores da Política Nacional enquanto que cabe à Suprema Corte o Controle de Constitucionalidade das Leis e Normas que vão embasar a atuação da administração pública). Estes agentes igualmente participam do Campo do Poder, porém com distância mínima, estão em posição pouco inferior aos elementos do Poder Legislativ na medida em que seu poder nomotético diminui (pouco) por não lhes ser concedida a atribuição constitucional de criar as leis (o nomos) do País.

Este é o quadrante relativo ao Campo do Poder da Política Educacional Brasileira, mas por se tratar de um modelo complexo de análise, há que tomar em consideração os demais agentes e estruturas dispersos em outros quadrantes representativos do Campo. Sigamos então ao quadrante em que o poder nomotético $(\mathrm{X}+)$ se sobrepõe ao poder político $(\mathrm{Y}-)$.

\section{O Campo e a estrutura de capital: poder nomotético sobreposto ao poder político}

$\mathrm{O}$ quadrante de coordenadas $\mathrm{X}+\mathrm{e} \mathrm{Y}$ - corresponde aos agentes e estruturas que possuem maior poder nomotético (no sentido de construir e dar sentido às normas) e menos poder político, nesta se encontram representados quatro elementos: A) Instituições/Estruturas: Ministério Público (MP) e Tribunais de Contas/Controladoria Geral da União (CGU): b) Agentes: Agentes do MP e Agentes dos Tribunais de Contas e CGU.

No tocante às estruturas, o poder nomotético incide mais fortemente sobre os Tribunais de Contas e CGU, de maneira que seu trabalho "técnico", ligado à correição e análise de orçamentos e normas administrativas de coloca no sentido de restringir e/ou modelar/revisar atos políticos e administrativos dos agentes e estruturas do Campo (quanto menos ligados ao Campo do Poder, maior esta ação regulatória). Ambos se posicionam em região de equivalência no que diz respeito ao poder político (ou volume de capital), expresso no "Eixo X", porém o MP devido a sua maior abrangência no que se refere à função de correição possui maior espectro de atuação, não se restringindo à análise da contabilidade pública mas antes abrangendo o controle externo da Administração Pública.

No que diz respeito aos agentes representados neste quadrante, de maneira análoga os integrantes do MP possuem maior poder político e os integrantes dos tribunais de contas maior poder nomotético, de modo que agentes e estruturas neste quadrante apresentam certa similitude e complementaridade quanto ao alcance de sua atuação, em especial quando considerada a sua ação sobre as políticas educacionais.

\section{Os “objetos" das Políticas Públicas representados graficamente: o quadrante no qual se concentra menor volume e estrutura de capital}

A região do Campo na qual estão localizados os "objetos das Políticas Públicas" (quadrante das coordenadas X- e Y-) coincide com os agentes e estruturas que possuem menor volume e estrutura de capital (Poder Político e Poder Nomotético). Temos neste quadrante seis elementos: a) Instituições/Estruturas: Associações Educacionais, Técnicas e Científicas, 
Secretarias de Educação (Municípios e Estados), Sindicatos de Profissionais da Educação; b) Agentes: dirigentes das associações educacionais, técnicas e científicas, secretários de educação, professores e gestores de instituições de educação superior e da Educação Básica.

Em relação às instituições/estruturas presentes neste quadrante $(\mathrm{X}-/ \mathrm{Y}-)$ percebemos certa complementaridade quanto à relação entre volume e estrutura de capital expressa nas posições do Campo. Assim, percebe-se que os agentes possuem maior poder nomotético, quando tomados em relação às instituições correlatas (ex: dirigentes de associações técnicocientíficas e as instituições representadas pelas associações técnico-científicas), de modo que este é um espaço no qual as posições do campo tendem a privilegiar a personalização dos agentes em detrimento da força coletiva das estruturas/instituições.

Isto posto, cabe notar que, em posição oposta ao quadrante do Campo do Poder, os “dominados entre os dominantes' para usar a célebre expressão bourdieuniana orientam sua distribuição no Campo também de forma inversa, o que não se verifica na extremidade deste quadrante, no qual se situam professores da Ed. Superior e professores da Educação Básica, posição esta na qual os primeiros possuem maior poder nomotético e poder político equivalente. Condição esta, aliás, que tem a ver com o modo dissonante como reagem aos ditames governamentais os professores quando não subsidiados por organizações sindicais fortes.

\section{Agentes e estruturas com maior volume de capital (poder político) e menor estrutura de capital: o quadrante das coordenadas $\mathrm{X}-\mathrm{e} \mathrm{Y}+$}

O quadrante referente aos agentes e estruturas com menor poder nomotético (X-) e maior poder político $(\mathrm{Y}+)$ possui quatro elementos: a) Instituições/estruturas: Movimentos Sociais e Conselhos da Sociedade Civil; b) Agentes: dirigentes de movimentos sociais e Conselheiros da Sociedade Civil. Neste quadrante estão presentes os elementos de mobilização política que não detém (mesmo que momentaneamente) o controle do nomos do Campo, muito embora possuam ampla capacidade de mobilização e articulação política.

No que se refere às instituições, estas possuem maior poder nomotético e poder político equivalente. Assim, os movimentos sociais em nível político, possuem uma distribuição de posições e paralelo com os seus integrantes, o que também ocorre com os Conselhos da Sociedade Civil e seus conselheiros. Isto tem a ver com um elemento de homologia estrutural: todos estes elementos institucionais são criados tendo em vista o princípio da Gestão Democrática e da Horizontalidade decisória. Assim sendo, a ênfase nas deliberações coletivas possui integração com o nomos intrínseco ao grupo representativo, o que se reflete nas já mencionadas posições paralelas.

É neste quadrante que se coloca o maior número de lutas e disputas do que pode vir a ser a illusio do Campo, bem como das futuras disposições e distribuições posicionais que refletem o estado do Campo da Política Educacional no Brasil.

\section{Limites e possibilidades do modelo analítico apresentado}

Conforme apresentado na seção anterior, houve uma aplicação da metodologia de análise de Campo a partir de eixos de coordenadas (X, Y) transpostas para diagramas posicionais construídas em função da estrutura e volume de capital de um Campo (no caso, o Campo da Política Educacional Brasileira). Este foi um esboço de modelo analítico que merece (como todo modelo teórico) sucessivas revisões e redimensionamentos, porém ao que tudo indica, atende à 
finalidade de representar graficamente o conceito de Campo quando aplicado a um dado objeto situado espacial e historicamente.

Para além da possibilidade de analisar o momento, e projetar o "devir" do campo, trazida pelo autor acima citado, é possível (e desejável) combinar os resultados de tal análise a outros esquemas gráficos, bem como aos procedimentos analíticos caros à análise documental e revisão bibliográfica. Antes, porém, cabem algumas considerações de natureza teórico-metodológica.

A primeira é a de que não existe Campo sem uma história que o preceda, e para entender um determinado status quo, há que remontar a esta história (o que será efetuado a seguir. A segunda consideração é a de que os elementos do Campo ganham ou perdem importância a partir da consideração de sua trajetória, a qual não possui elementos de representação no sistema analítico proposta e apresentado anteriormente.

Tendo em vista estas considerações passemos então a um estudo de caráter históricopolítico das Políticas Públicas, em especial as Políticas Públicas Educacionais do Brasil, procuramos na subseção que vem a seguir apresentar uma trajetória histórico-política do Campo, que vem a ser complementar ao modelo analítico apresentado.

\section{A trajetória (de agentes e estruturas) como resultante das interações do Campo história, lutas e conflitos materializados no status quo do Campo (e do Campo do Poder)}

Em face do que já fora exposto, o estado de um Campo é uma resultante em dois sentidos: a) Das forças que o compõem tomadas em seu momentuum e assim percebidas como uma espécie de quadro imagético no qual as posições detidas por agentes e estruturas apresentam uma configuração aparentemente estanque; b) Todo Campo possui uma história e permitir a antecipação de cenários. Sendo uma resultante de forças, quanto menos consolidadas as posições de agentes e estruturas, maior o dinamismo deste Campo e maior o efeito de trajetória exercido por agentes e estruturas.

Conforme fora exposto anteriormente, a estrutura de capital (especialmente) detida por agentes e estruturas em dado Campo está condicionada por um epifenômeno decorrente de sua circulação em outros campos, qual seja, a assimilação por intermédio do Habitus de experiências concernentes aos dados campos e que geram reflexos e condicionamentos incidentes sobre o senso prático dos agentes e sobre as normas das estruturas sociais presentes no Campo.

De igual modo, a illusio (como sentido do jogo) tende a ser melhor assimilada por agentes que circulam (e adquirem capitais) em diversos espaços sociais (e simbólicos) e por estruturas que fazem convergir grandes quantidades de capitais (em estrutura e volume) para sua composição (organizacional e simbólica). Fazendo uma analogia com a Fisica Einsteniana da relatividade, tais agentes e estruturas promovem "deformações no Campo" tal como corpos celestes de grande massa promovem deformações no espaço-tempo. Tais deformações fazem convergir capitais (e agentes) que impactam a dinâmica do campo, seja modificando as normas do Campo (e sua Illusio), seja promovendo mudanças nos agentes e estruturas que vem a afetar a Illusio deste campo, bem como, por um efeito de ressonância o valor dos capitais detidos pelos elementos deste Campo, o que implica em conversões e reconversões de capitais (tanto nas passagens dos agentes entre os Campos, quanto nas mudanças de posição dos agentes em relação às estruturas do Campo). 
No que diz respeito ao que foi apresentado, para compreender o caráter multidimensional (bem como as múltiplas determinações e condicionamentos oriundos da trajetória de agentes e estruturas do Campo) se faz necessário remontar a uma história estrutural (e simbólica) do campo.

Assim, em relação ao Campo da Política Educacional Brasileira, será apresentada uma breve história do referido Campo da Política Educacional no Brasil, levando em consideração o exercício de análise que incorporou os elementos teórico-metodológicos já explicitados, de maneira que a seguir são apresentados os resultados desta empreitada teórico-metodológica aplicada às políticas públicas educacionais.

\section{Marcos históricos do campo das políticas educacionais do Brasil após 1988}

A partir do processo de redemocratização do país, com o fim da Ditadura Civil-Militar (1964-1985) e a publicação da nova Constituição (1988), iniciou-se o debate sobre as novas diretrizes e bases da educação nacional. Naquele momento, a lei geral da educação vigente datava de 1961 e já tinha sido atravessada por normatizações ocorridas durante o regime de exceção, como as leis 5.540, de 1968 (reforma do sistema universitário) e 5.692, de 1971 (reforma do ensino básico). De acordo com Saviani,

Antes mesmo que os constituintes entrassem em ação, a IV Conferência Brasileira de Educação, realizada em Goiânia em agosto de 1986, teve como tema central "A educação e a constituinte". E na assembleia de encerramento dessa Conferência foi aprovada a "Carta de Goiânia" contendo as propostas de educadores para o capítulo da Constituição referido à educação (SAVIANI, 2008, p. 35).

Portanto, confirma-se que a legislação sobre a educação já era pauta antes mesmo da formação da Assembleia Nacional Constituinte. Isso fez com que o primeiro projeto de uma nova LDB fosse apresentado ao Congresso ainda em 1988, por iniciativa do deputado Otávio Elísio (PMDB). As intensas disputas sobre o projeto de educação que se queria, entre forças conservadoras e progressistas, fez com que a lei só fosse aprovada, de fato, em 20 de dezembro de 1996, trazendo uma redação completamente diferente do projeto inicial e com a chancela autoral de Darcy Ribeiro.

Após aprovação da Constituição Federal de 1988, o Brasil pôde eleger seu primeiro Presidente por vias democráticas desde a eleição de Jânio Quadros, em 1960. Elegeu-se Fernando Collor de Melo, pertencente a uma família política tradicional de Alagoas, que trazia um discurso moralizador e, em certa medida, progressista. Mesmo tendo ficado pouco tempo no poder (1990 a 1992), após renunciar a partir de graves denúncias de corrupção, Collor abriu as portas do Brasil para o capitalismo, algo que a Ditadura não havia feito. O país começa a se comportar como país capitalista periférico e inicia-se um período de enxugamento do Estado e incentivo ao livre mercado.

O Vice-presidente de Collor, Itamar Franco, cumpre seu mandato até o fim e torna-se pai do Plano Real, que buscou modernizar o sistema monetário nacional, até então vítima de uma aguda crise e de uma hiperinflação que atingia cifras astronômicas. O seu Ministro da Fazenda era o sociólogo Fernando Henrique Cardoso que, a partir do sucesso da nova moeda, se qualificou politicamente para ser o novo Presidente (1994-2002). 
Do ponto de vista da orientação política e econômica, temos uma linha contínua que atravessa os três governos citados, ainda que com particularidades em cada um. No Governo Fernando Henrique Cardoso, as influências de organismos multilaterais como a Organização das Nações Unidas, o Banco Mundial e o Fundo Monetário Internacional passam a ser consideradas de alta relevância nas tomadas de decisão, da mesma maneira que já ocorria em países de capitalismo central ${ }^{12}$.

Para Altmann (2002), as propostas do Banco Mundial foram as mais influentes no campo educacional brasileiro, na medida em que o organismo tem declarado, desde 1990, que seu principal objetivo é o combate à pobreza, tendo a oferta de ensino elementar como uma das suas principais recomendações. O próprio programa de governo de Fernando Henrique Cardoso trazia claramente vinculações com as prescrições do Banco Mundial.

O ápice desse entrelaçamento entre o Brasil e Banco Mundial se dá em 1995, com Reforma Gerencial do Estado, comandada pelo então Ministro Luiz Carlos Bresser-Pereira. Neste ano foi implementado o "Plano Diretor da Reforma do Aparelho do Estado", conduzido pelo Ministério da Administração Pública e Reforma do Estado. Segundo o documento:

É preciso, agora, dar um salto adiante, no sentido de uma administração pública que chamaria de "gerencial", baseada em conceitos atuais de administração e eficiência, voltada para o controle dos resultados e descentralizada para poder chegar ao cidadão, que, numa sociedade democrática, é quem dá legitimidade às instituições e que, portanto, se torna "cliente privilegiado" dos serviços prestados pelo Estado. É preciso reorganizar as estruturas da administração com ênfase na qualidade e na produtividade do serviço público; na verdadeira profissionalização do servidor, que passaria a perceber salários mais justos para todas as funções. Esta reorganização da máquina estatal tem sido adotada com êxito em muitos países desenvolvidos e em desenvolvimento (BRASIL, 1995, p. 7).

$\mathrm{Na}$ educação, recorre-se a quatro diferentes conjuntos de políticas públicas para exemplificar como esta perspectiva gerencialista do Estado influenciou - e ainda hoje influencia a agenda nacional. São elas: as políticas de currículo, as políticas de avaliação, as políticas de valorização e as políticas de financiamento educacional. Há outras políticas que poderiam ser consideradas, mas essas quatro traduzem o que há mais latente na reconstituição da educação brasileira a partir de uma lógica de "quase mercado" (SOUZA; OLIVEIRA, 2003).

Uma das primeiras orientações do Banco Mundial cumpridas pelo Governo Fernando Henrique Cardoso (vale lembrar que o Ministro da Educação à época era Paulo Renato de Souza, técnico de carreira do Banco Mundial) foi a instituição de uma nova política curricular. Uma das prescrições do órgão aponta para a padronização do ensino no território nacional, a fim de poder gerar elementos de comparação. Por isso a centralidade de investimentos em livros-textos é uma importante recomendação para países que contraem empréstimos.

No bojo dessas orientações, o Ministério da Educação convidou importantes pesquisadores como consultores para elaborarem os Parâmetros Curriculares Nacionais (PCNs), que deveriam servir como orientações para as escolas definirem o que deveriam ensinar. Em 1997, foram publicados os primeiros PCNs, seguidos pelos Referenciais Curriculares para a Educação Infantil. Como aponta Cunha (1996), a LDB aprovada um ano antes tinha uma concepção minimalista e não se debruçava sobre aspectos cruciais da educação, como o debate

${ }^{12}$ Fazemos aqui a distinção entre países de capitalismo central (desenvolvidos) e países de capitalismo periférico (em desenvolvimento), como os países da América Latina. Para maior aprofundamento ver Santos (2014). 
sobre currículo ou avaliação. Sendo assim, novas políticas tiveram que ser formuladas para dar conta das fragilidades do texto legal, seguindo a receita de doses homeopáticas, como ironiza Saviani (2008).

A discussão a respeito dos PCNs foi intensa e culminou na reformulação das Diretrizes Curriculares Nacionais em todos os níveis, uma vez que o Conselho Nacional de Educação entendeu que os Parâmetros não deveriam ser obrigatórios. Hoje, esse debate se arrasta para a definição da Base Nacional Curricular Comum, que engessa ainda mais o trabalho docente com vistas às avaliações em larga escala.

Nas políticas de avaliação, o marco mais importante é a criação do Sistema de Avaliação da Educação Básica - SAEB - ainda em 1988, seguindo os moldes do PISA ${ }^{13}$. O SAEB surgiu como uma prova amostral e hoje constitui-se como um verdadeiro sistema avaliativo, agregando outros instrumentos como a Prova Brasil, a Avaliação Nacional da Alfabetização (ANA) e o Exame Nacional do Ensino Médio (Enem). A avaliação em larga escala, como apontam Souza e Oliveira (2003, p. 875), "torna-se peça central nos mecanismos de controle" e "legítima 'valorações' úteis à indução de procedimentos competitivos entre escolas e sistemas para melhorar pontuações nos rankings [...]".

Ressalta-se que as políticas avaliativas tomaram grande corpo e mesmo nos governos seguintes (Luiz Inácio Lula da Silva, 2003-2010 e Dilma Roussef 2011-2016), com orientações político-ideológicos diferentes dos governos anteriores, houve investimento e aperfeiçoamento das estratégias avaliativas enquanto mecanismos de controle. Essas políticas trazem à tona a ideia de um Estado Avaliador, que possibilita a descentralização das práticas pedagógicas, mas, no final do processo, exige que todos passem pelos mesmos critérios em exames e testes unificados.

Os resultados das políticas avaliativas produzem o que convencionou-se chamar de efeitos de responsabilização ou accountability (BALL, 2005; HYPOLITO, 2010). Trata-se de um sistema de prestação de contas, que direciona à escola, aos gestores e professores a responsabilidade exclusiva pelo sucesso ou pelo fracasso dos alunos. Esse modelo, baseado na lógica do mérito, acaba por comprometer o trabalho docente, na medida em que os objetivos passam a ser o resultados e não a qualidade dos processos. Isso impacta nas políticas de valorização, que passaram a ter como medidas os resultados em testes em larga escala e índices impostos pelo governo.

Em 2007, já no Governo Lula, foi criado o Ideb, Índice de Desenvolvimento da Educação Básica, indicador calculado com base no fluxo dos estudantes e nos resultados dos mesmos em testes estandardizados. A partir da divulgação dos primeiros resultados, começou-se a colher os primeiros efeitos no que tange à meritocracia. Diversos sistemas municipais e estaduais (inclusive a cidade do Rio de Janeiro) passaram a adotar políticas de remuneração variável (HYPOLITO, 2010), baseadas em resultados do Ideb.

A lógica gerencialista da reforma do Estado atingiu seu ápice (ou pelo menos espera-se), na medida em que as escolas públicas passaram a se comportar de fato como empresas, com metas e bônus por cumprimento, ainda que, antes da instituição do índice, já se experimentasse no país um processo de flexibilização e precarização do trabalho docente (OLIVEIRA, 2004).

\footnotetext{
${ }^{13}$ O Programme for International Student Assessment (Pisa) - Programa Internacional de Avaliação de Estudantes - é uma iniciativa de avaliação comparada, aplicada de forma amostral a estudantes matriculados a partir do $8^{\circ}$ ano do ensino fundamental na faixa etária dos 15 anos, idade em que se pressupõe o término da escolaridade básica obrigatória na maioria dos países. O Pisa é coordenado pela Organização para Cooperação e Desenvolvimento Econômico (OCDE), havendo uma coordenação nacional em cada país participante. No Brasil, a coordenação do Pisa é responsabilidade do Inep.
} 
A precarização do trabalho passa, sobretudo, pelas políticas de financiamento da educação. Por mais que tenham ocorrido iniciativas para reestruturar o financiamento da educação, como a criação do FUNDEF (Fundo de Manutenção e Desenvolvimento do Ensino Fundamental e de Valorização do Magistério) em 1996, não houve, de fato, uma grande injeção de recursos que pudessem transformar o cenário de precarização de escolas e salários até o Governo Dilma Rousseff. Nele (BRASIL, 2014), foi aprovado o Plano Nacional de Educação (2014-2024), que estabelece, em sua meta 20, que até o final de sua vigência, $10 \%$ do Produto Interno Bruto brasileiro deve ser direcionado ao financiamento da educação.

O desmonte do Plano Nacional de Educação é um desastre anunciado, justificado pela recessão econômica e pelas claras orientações neoliberais do Governo Temer, iniciado após o impeachment de Dilma Rousseff, em 31 de agosto de 2016. Possivelmente, com a chegada da extrema-direita ao poder, teremos nova retração das políticas sociais, dentre elas as educacionais e uma tentativa de transferência do Estado para a iniciativa privada de responsabilidades até então constitucionais, como a oferta de educação básica, como as novas lideranças já anunciaram em discursos de campanha.

\section{A compreensão das políticas educacionais como campo}

O enquadramento das políticas públicas como objeto de pesquisas acadêmicas é relativamente recente. Somente nas últimas três décadas passamos a encontrar textos que tratam especificamente das políticas públicas como elemento central, desvinculando-as de uma discussão mais ampla sobre teoria/ciência política ou sobre o papel do Estado. Ainda que o isolamento do termo policy analysis - análise de política pública - tenha sido realizado por Harold Laswell em 1936 (SOUZA, 2006), houve um longo caminho para que a política pública inaugurasse, de fato, um campo de estudos.

Além de Laswell, Souza (2006) aponta como pais fundadores da área de políticas públicas Herbert Simon, Charles Lindblom e David Easton. Segundo a autora, Simon, em 1957, trabalhou pela primeira vez com a perspectiva de policy makers (racionalidade limitada de formuladores de políticas), tratando das disputas entre os decisores das políticas; já em 1959, Lindblom, se aprofundou nas relações de poder e a integração de diferentes fases do processo decisório; Easton, em 1965, foi o primeiro a tratar a política pública como um sistema, estabelecendo relações entre formulação, resultados e o ambiente.

Todos esses teóricos foram fundamentais para a constituição do campo teórico que hoje é entendido como política pública. A partir das primeiras iniciativas de construção de um estado de bem-estar social, nos Estados Unidos, após a Primeira Guerra Mundial, as discussões acerca das políticas públicas ganharam relevância, na medida em que foram colocadas em prática. Destacamos três conceituações de importantes pensadores brasileiros sobre o tema, a saber:

[...] o conceito de políticas públicas implica considerar os recursos de poder que operam na sua definição e que têm nas instituições do Estado, sobretudo na máquina governamental, o seu principal referente. (AZEVEDO, 2004, p. 5).

[...] campo do conhecimento que busca, ao mesmo tempo, 'colocar o governo em ação' e/ou analisar essa ação (variável independente) e, quando necessário, propor mudanças no rumo ou curso dessas ações (variável dependente). (SOUZA, 2006, p. 26). 
[...] uma forma contemporânea de exercício do poder nas sociedades democráticas, resultante de uma complexa interação entre o Estado e a sociedade, entendida aqui num sentido amplo, que inclui as relações sociais travadas também no campo da economia. (DI GIOVANNI, 2009, p. 5).

$\mathrm{Na}$ definição trazida por Azevedo, a discussão sobre o poder - e sobre as formas de poder - se faz presente, colocando o Estado, mais precisamente o governo, como protagonista das políticas públicas. A partir do pensamento de Poulantzas (1980 apud AZEVEDO, 2004, p. 5), a autora entende que as estruturas de dominação estatal condensam os conflitos infiltrados no tecido social. Nessa perspectiva, o Estado é o principal formulador das políticas públicas, que derivam dos embates entre as demandas sociais e a contraposição dos governos.

Souza vai mais adiante em seu entendimento, na medida em que retira do Estado o papel exclusivo de ação. Segundo suas colocações, a política pública visa colocar o governo em ação. Logo, entende-se que a política pública não é necessariamente uma instância governamental, mas uma influência, uma variável para a ação do Estado ${ }^{14}$. Nesta conceituação, a política pública serve, inclusive, para alinhar perspectivas e reorganizar ações que já estão em curso.

Di Giovanni aprofunda a percepção de Souza, reforçando o dinamismo das políticas públicas, mas cria alguns recortes que merecem destaque. Primeiramente, o autor condiciona as políticas públicas a sociedades democráticas, recuperando o sentido latino do termo público publicus - relativo ao povo. Ele trata as políticas públicas como formas de enfrentamento entre Estado e sociedade, numa trama que passa pelas questões econômicas. Em segundo lugar, para o autor, as políticas públicas possuem estruturas elementares que fazem com que se não sejam armas exclusivas de um Estado interventor.

As estruturas elementares citadas por ele são: a estrutura formal, que compreende a análise da teoria, da prática e dos objetivos das políticas; a estrutura substantiva, que relaciona os atores, os interesses e as regras impostas aos ritos; a estrutura material, que passa pela questão do financiamento e dos suportes necessários para a efetivação das políticas; e a estrutura simbólica, a mais densa de todas, que trabalha com os valores, saberes e linguagens das políticas e de seus formuladores (DI GIOVANNI, 2009).

Tais concepções podem ser analisadas à luz da visão bourdiesiana, como objetos teóricos, na medida em que a posição dos elementos do campo contrariam a ideia de linearidade estrutural. Assim, como campo teórico-epistemológico, a inter-relação entre os objetos e suas variações ajudam a definir a estrutura. Poderíamos dizer que trata-se, também, de um campo de produção, entendendo que dentro de cada campo existem situações análogas, baseadas naquilo que Bourdieu (2001b, p. 217) trataria por "homologias funcionais e estruturais", ou seja, um padrão de repetição de certas estruturas e funções sociais.

A entrada da educação no rol dos direitos sociais garantiu a ela um novo status político e econômico no mundo contemporâneo. Como afirma Cury (2002), praticamente não há país no mundo que não garanta o acesso à educação básica em suas leis, seja por esta ter se constituído como dimensão fundante da ideia de cidadania, seja pelas demandas exigidas pelo mundo do trabalho.

\footnotetext{
${ }^{14}$ Nesta discussão, está tratando-se governo e Estado como sinônimos, mesmo com a compreensão de que representam instâncias políticas distintas, que podem vir a convergir em determinados momentos.
} 
Os conceitos de campo e habitus em Pierre Bourdieu e sua (possível) aplicação à Política Educacional

Não são poucos os documentos de caráter internacional, assinados por países da Organização das Nações Unidas, que reconhecem e garantem esse acesso a seus cidadãos. Tal é o caso do art. XXVI da Declaração Universal dos Direitos do Homem, de 1948. Do mesmo assunto ocupam-se a Convenção Relativa à Luta contra a Discriminação no Campo do Ensino, de 1960, e o art. 13 do Pacto Internacional dos Direitos Econômicos, Sociais e Culturais, de 1966. (CURY, 2002, p. 246).

Sendo assim, atualmente há um consenso em torno da necessidade de oferta da educação básica como elemento central do desenvolvimento dos países. A educação passa a ser, globalmente, um direito social, que requer para si um sistema de normatizações, a fim de que possa acontecer de fato. A partir desta demanda, começam a se desenvolver as políticas educacionais em todos os âmbitos e esferas, com o objetivo de dar forma concreta ao direito, que até então permanece no campo da intenção.

No Brasil, após longo período de Ditadura Civil-Militar, a Constituição Federal de 1988 traz, em seu capítulo II, a educação como direito social. No Art. 208, há o seguinte parágrafo: "S $1^{\circ} \mathrm{O}$ acesso ao ensino obrigatório e gratuito é direito público subjetivo" (BRASIL, 1988). Esta normatização é de grande importância, pois ela coletiviza e, ao mesmo tempo, individualiza o direito à educação obrigatória definido em lei. O direito público é o direito de todos; o direito subjetivo é o direito do sujeito, que pode ser cobrado a qualquer tempo, por qualquer um. A obrigatoriedade da educação escolar para determinado grupo etário fez com que uma vultosa soma de recursos fosse direcionada ao atendimento desse direito. Se no Império, menos de $2 \%$ da arrecadação de impostos era destinada à educação (SAVIANI, 2010), hoje a Constituição obriga que sejam empregados, pelo menos, $18 \%$ pela União e $25 \%$ por Estados e Municípios.

Recuperando as estruturas apontadas por Di Giovanni (2009), a estrutura material é um importante condicionante das políticas públicas. Sendo assim, a destinação de grandes cifras orçamentárias para a área educacional aumenta consideravelmente as disputas por projetos de poder. A maximização da estrutura material (financiamento) produz consequências nas demais estruturas, influenciando práticas, interesses e valores. A própria definição da educação como campo parece ser difusa, na medida em que, dada a sua impossibilidade de constituir-se como ciência autônoma, graças também ao seu caráter interdisciplinar, acabamos por vezes nos referindo ao campo teórico (e de produção) das políticas públicas educacionais.

Ozga (2000) estudou o campo das políticas educacionais sob um prisma epistemológico. A premissa do seu texto é que as políticas educacionais são objetos de interesse da comunidade educativa e que não devem representar ou estar a serviço exclusivo dos decisores políticos. Seu entendimento é de que a "[...] política é algo sobre o qual se discute, que não se oferece, em lápides de pedra, a populações que se mostram receptivas e gratas por isso [...]" (OZGA, 2000, p. 19). Segundo a autora, não há uma clara distinção entre o campo da política educacional e campo das políticas sociais, o que dificulta as investigações especializadas. Tampouco os professores, os maiores interessados nos resultados das investigações, se sentem parte do campo científico, não se enxergam como intelectuais, o que impede o escrutínio das ações sobre a educação. De acordo com suas proposições, são as próprias pesquisas já realizadas que encorajam os profissionais da educação a realizarem novas, a esmiuçarem novos objetos e a desenvolverem pensamentos críticos e reflexivos face à política (OZGA, 2000).

Assim, tratando a política educacional como uma campo relativamente autônomo, na medida em que possui seus próprios agentes, capitais, suas formas de subordinação, doutrinação, legitimação e violência simbólica, fizemos um apanhado dos principais marcos estruturantes, desde o período de redemocratização (1988) até anos recentes, com o intuito de estabelecer 
marcos históricos que sirvam de guias teóricos e epistemológicos para os estudos de uma determinada matriz ideológica, alinhada à perspectiva bourdiesiana de Estado.

\section{Considerações finais}

O campo das políticas públicas em educação é entendido, neste artigo, como estrutura pensada e proposta por distintos atores, inclusive o Estado, com objetivo de fortalecer a ação pública frente à privada. Nesse sentido, o conceito de política pública se aproxima do de política social, enquanto instâncias socializadoras de oportunidades. O problema é que há corruptelas do termo, adotadas inclusive em perspectivas neoliberais.

Howlett, Ramesh e Perl (2013, p. 7) partem de uma perspectiva tecnocrática para justificarem que as políticas públicas são simplesmente "iniciativas sancionadas por governos". Ou seja, segundo os autores, bastaria a anuência do governo a determinada ação para a mesma ser considerada de interesse público. Isso abre margem para a autorização de concessões e privatizações, transferência de dinheiro público para a iniciativa privada e tantas outras aberrações que são cada vez mais comuns no contexto brasileiro e mundial.

A pesquisa sobre políticas educacionais deve ser precedida de afirmações teóricoepistemológicas, mas também ideológicas, daquilo que se entende por educação, Estado e política pública. Essas conceituações marcam, não apenas o teor científico, mas também político do campo e da pesquisa, afirmando o babitus do pesquisador e influenciando reflexivamente o mundo social. Por isso, a pesquisa tem um compromisso que vai além da reunião e triangulação de dados, mas passa pela constituição da ciência.

É, portanto, necessário trazer a dupla reflexibilidade do conceito de campo e habitus para o âmbito da pesquisa em políticas educacionais, pois da mesma forma que um campo somente tem sentido quando ele é definido em sua interação com os demais campos, a sua estrutura interna, por sua vez, sofrerá um efeito de interação entre agentes e estruturas simbólicas, sociais, culturais e políticas inerentes às especificidades da geração do seu campo particular, as quais, conforme já dizia muito acertadamente Gaston Bachelard (2001), são nada mais nada menos do que casos particulares do possível.

\section{Referências}

ALTMANN, H. Influências do Banco Mundial no projeto educacional brasileiro. Educação e Pesquisa, São Paulo, v. 28, n. 1, p. 77-89, jan./jun. 2002. DOI: https://doi.org/10.1590/s1517$\underline{97022002000100005}$

AZEVEDO, J. A educação como política pública. Campinas: Autores Associados, 2004.

BACHELARD, G. A formação do Espírito Científico. Rio de Janeiro: Contraponto, 2001.

BALL, S. Profissionalismo, gerencialismo e performatividade. Cadernos de Pesquisa, São Paulo, v. 35, n. 126, p. 539-564, set./dez. 2005. DOI: https://doi.org/10.1590/s0100$\underline{15742005000300002}$

BOURDIEU, P. A distinção: crítica social do julgamento. São Paulo: Martins Fontes, 2001a.

BOURDIEU, P. O poder simbólico. Rio de Janeiro: Bertrand Brasil, $2001 \mathrm{~b}$. 
Os conceitos de campo e habitus em Pierre Bourdieu e sua (possível) aplicação à Política Educacional

BOURDIEU, P.; CHAMBOREDON, J.; PASSERON, J. O ofício de sociólogo. Petrópolis: Vozes, 2004.

BRASIL. Plano Diretor da Reforma do Aparelho do Estado. Brasília, DF: Presidência da República; Câmara da Reforma do Estado, 1995. Disponível em: <http://www.biblioteca.presidencia.gov.br/publicacoes-oficiais/catalogo/fhc/plano-diretor-dareforma-do-aparelho-do-estado-1995.pdf $>$.

BRASIL. Constituição (1988). Constituição da República Federativa do Brasil. Brasília, DF: Senado, 1988.

BRASIL. Lei no 13.005, de 25 de junho de 2014. Aprova o Plano Nacional de Educação - PNE e dá outras providências. Diário Oficial da União, Brasília, DF, 26 jun. 2014.

BRASIL. Lei n ${ }^{\circ}$ 13.414, de 10 de janeiro de 2017. Estima a receita e fixa a despesa da União para o exercício financeiro de 2017. Diário Oficial da União, Brasília, DF, 11 jan. 2017.

CASSIRER, E. Uma filosofia das formas simbólicas. São Paulo: Martins Fontes, 2001.

CUNHA, L. A. Crise e reforma do sistema universitário (debate). Novos Estudos - CEBRAP, São Paulo, p. 143-168, n. 46, nov. 1996.

CURY, C. R. J. Direito à educação: direito à igualdade, direito à diferença. Cadernos de Pesquisa, São Paulo, n. 116, p. 245-262, jul. 2002. DOI: https://doi.org/10.1590/s0100$\underline{15742002000200010}$

DI GIOVANNI, G. As estruturas elementares das políticas públicas. Cadernos de Pesquisa NEPP/UNICAMP, Campinas, n. 82, p. 1-29, 2009.

HOWLETT, M.; RAMESH, M.; PERL, A. Políticas públicas: seus ciclos e subsistemas, uma abordagem integral. Rio de Janeiro: Elsevier, 2013.

HYPOLITO, A. M. Políticas curriculares, Estado e regulação. Educação \& Sociedade, Campinas, v. 31, n. 113, p. 1337-1354, out./dez. 2010. DOI: https://doi.org/10.1590/s0101$\underline{73302010000400015}$

LANE, J. Bourdieu's politics: problems and possibilitys. New York: Routledge, 2006.

OLIVEIRA, D. A. A reestruturação do trabalho docente: precarização e flexibilização. Educação \& Sociedade, Campinas, v. 25, n. 89, p. 1127-1144, set./dez. 2004. DOI: https://doi.org/10.1590/s0101-73302004000400003

OZGA, J. Investigação sobre políticas educacionais: terreno de contestação. Porto, Portugal: Porto Editora, 2000.

SANTOS, P. S. M. B. A Aplicabilidade dos conceitos de habitus e campo a um a pesquisa em História da Educação. Dialogia, São Paulo, v. 6, n. 2, jul./dez. 2007.

SANTOS, P. S. M. B. Questões polêmicas de política e legislação educacional. Curitiba: Editora CRV, 2012.

SANTOS, P. S. M. B. Princípios da metaciência social. Jundiaí: Paco Editorial, 2013. 
SANTOS, P. S. M. B. Campo do poder, refração política e legislação educacional: notas para uma discussão da gestão democrática no Brasil. Revista Ibero-Americana de Estudos em Educação, Araraquara, v. 9, n. 4, p. 969-984, abr. 2014.

SANTOS, T. Teoria da dependência: balanços e perspectivas. Florianópolis: Insular, 2014.

SAVIANI, D. A nova lei da educação: trajetória, limites e perspectivas. Campinas: Autores Associados, 2008.

SAVIANI, D. História das ideias pedagógicas no Brasil. Campinas: Autores Associados, 2010.

SOUZA, C. Políticas públicas: uma revisão de literatura. Sociologias, Porto Alegre, v. 8, n. 16, p. 20-45, jul./dez. 2006. DOI: https://doi.org/10.1590/s1517-45222006000200003

SOUZA, S. Z. L.; OLIVEIRA, R. P. Políticas de avaliação da educação e quase mercado no Brasil. Educação \& Sociedade, Campinas, v. 24, n. 84, p. 873-895, set. 2003. DOI: https://doi.org/10.1590/s0101-73302003000300007

TEIXEIRA, A. Ciência e arte de educar. Educação e Ciências Sociais. v. 2, n. 5, p. 5-22, ago. 1957.

TRIVIÑOS, A. N. S. Introdução à pesquisa em Ciências Sociais: a pesquisa qualitativa em educação, São Paulo: Atlas, 1987.

Recebido: 10/11/2018

Versão corrigida recebida: 02/02/2019

Aceito: 04/02/2019

Publicado online: 11/02/2019

\section{Jorge Nassim Vieira Najjar}

Doutor em Educação pela USP. É Professor Adjunto IV pelo Departamento de Educação, Sociedade e Conhecimento da Faculdade de Educação da Universidade Federal Fluminense. Lidera o Núcleo de Estudos em Gestão Educacional, Politicas Públicas e Educacionais - Nugeppe. Autor de livros e artigos publicados em periódicos nacionais e internacionais.

\section{Marcelo Siqueira Maia Vinagre Mocarzel}

Doutor em Comunicação Social pela Puc-Rio. É Professor Adjunto da UNILASALLE no Departamento de Educação desta Universidade. É pesquisador integrante do Nugeppe. Autor de livros e artigos publicados em periódicos nacionais e internacionais.

\section{Pablo Silva Machado Bispo dos Santos}

Doutor em Educação pela Puc-Rio. Professor Associado I do Departamento de Ciências Humanas da Universidade Federal Fluminense. É pesquisador integrante do Nugeppe. Autor de livros e artigos publicados em periódicos nacionais e internacionais. 